\title{
Theoretical interrelationships between television studies and excess in media discourse
}

\author{
Anderson Lopes da Silva ${ }^{1}$
}

University of São Paulo, Brazil

To cite this article: Lopes da Silva, A. (2020). Theoretical interrelationships between television studies and excess in media discourse. World of Media. Journal of Russian Media and Journalism Studies 4: 57-79. DOI: 10.30547/worldofmedia.4.2020.3

\begin{abstract}
This article aims to bring five possible views on the theoretical and compound relationships between excess and television. Therefore, the hyperbolic excess, semiotic excess, stylistic excess, bodily excess, and palimpsestic excess are brought into the discussion as combinatorial aesthetic modalities that permeate the TV media discourse. More than just systematizing the debate on such theoretical combinations, what is concluded in this work is that television is based on an ontological vision where the excess is understood as a qualitative discursive production. Consequently, the excess is present in the television language and is an intrinsic part of its form as a medium of social and cultural communication.
\end{abstract}

\section{Keywords}

Excess, discourse, language, style, television.

\section{Introduction}

In spaces such as academia or communication markets it is not unusual that discussions about the end of television or even debates on the gradual loss of its relevance in a consumer society are spread on a daily basis. Therefore, in a shift strong enough to be worthy of attention, it is also undeniable how streaming and its platforms have reinvented current audiovisual communication practices, processes, and products, such as the issue of rewatchability (Innocenti and Pescatore, 2014; Ladeira, 2016; Mittell, 2011; Smith and Telang, 2017).

\section{${ }^{1}$ Corresponding author:}

Anderson Lopes da Silva, University of São Paulo,

School of Communications and Arts, São Paulo, Brazil. Av.

Prof. Lúcio Martins Rodrigues, 443 - Butantã, São Paulo - SP, 05508-020.

E-mail: anderlopps@gmail.com 
However, there are a significant number of intellectuals - so enchanted with the 'new' in media technology and communications - who seem to be the official representatives announcing the early death of TV, or at least fervently making it clear that television's glory days are nearing an end. As heralds proclaim an imminent tragedy, these voices mislead the debates about the importance of TV in the construction of the social fabric in our current societies, as Carlón and Fechine (2014) critically affirm.

Equally, researchers such as Carlón and Scolari (2009) have been putting this issue on the academic agenda when reflecting on the relevance and continuity of television today. For the authors, TV is the co-protagonist in the media landscape alongside other contemporary technological media. Mittell (2010) also observes how television is a complex and multifaceted medium. Thus, to proclaim the end of television is to ignore its functions as 'a commercial industry, a democratic institution, a textual form, a site of cultural representation, a part of everyday life, and a technological medium' (Mittell, 2010).

In other words, some antiquated discussions ignore very complex foundations bases of adaptation, continuity, rupture, and innovation of the narrative, discursive, and technological processes of the television itself (Buonanno, 2015; Katz, 2009; Miller, 2009; Missika, 2006). This is in spite of television historically carrying with it contempt and even cultural delegitimation when it comes to understanding it as a relevant production and aesthetic process, as MartínBarbero (2009) and Fahle (2006, 2018) point out.

Thus, when the debate turns to considering the TV and its communication process and products, it is not rare that words such as 'excess' and 'excessive' are used in a way to (de)qualify in this kind of media discourse. Especially in fictional works such as series, miniseries, soap operas, and telenovelas are the places where the term excess is almost always present (Thorburn, 1976). In this sense, this study aims to look at the theoretical interrelationships between television studies and excess in terms of materialities, language, and aesthetic and stylistic textuality.

The main research question of this work is to understand how the theoretical interrelationships between excess and television studies take place in the media discourse. As a matter of fact, the media discourse is considered the locus of priority enunciation of these interrelationships. Thus, excess is seen in this article as an aesthetic-stylistic element that has three main characteristics that define such terminology: 
- Pervasiveness (the fluidity of excess allows it to pass through different genres $^{2}$, formats, and types of products present in broadcast and cable $\mathrm{TV}$, and enables the excess not to be restricted only to productions considered 'excessive' (i.e., soap operas, telenovelas, series, etc.);

- Ontologically qualitative (that is, excess is notseen as something unnecessary that can be thrown away and, thus, would be useless in quantitative terms);

- Composite configurations (the discursive enunciations of excess are multifaceted, that is, the empirical materiality of excess is distributed in varying intensities. Additionally, such composite modulations can be apprehended in terms of content, representation, fruition, form, aesthetics, and style).

Hence, the structure of this work is organized by the systematization of five possible views on the relationship between excess and television as forms of theoretical compositions that can be read and applied in the media discourse: hyperbolic excess, semiotic excess, stylistic excess, bodily excess, and palimpsestic excess. The starting point is to specify that the conceptual understanding of excess needs to be recognized and framed in ways that come out of a superficial and associative reading in which excess is understood as something unreasonable or an unnecessary shoddy surplus.

Accordingly, the research bibliography (understood as the main methodological path) is seen as a viable way to gather the views on excess in its interrelationship with television studies. The research bibliography aims to establish how different academic contributions are accessible on the central topic, demarcating their similarities and specific approaches. Finally, it is necessary to note that the possible limitations of this article are situated in the theoretical choices that are consciously and explicitly linked to Western authors and theories. Besides the five concepts discussed here, it is not inconceivable that other categories and interpretations of excess can be observed in works that allude to or focus on television studies under an Eastern gaze.

The geographic scope of these reflections is located in the American, British, and Latin American (especially Brazilian) televisiographies ${ }^{3}$. More than just

\footnotetext{
${ }^{2}$ However, it should be noted that in this work the focus is mainly on productions in the entertainment field.

${ }^{3}$ The neologism 'televisiography' is defended by Muanis (2015) as a conceptual analogy to the term cinematography. For the author, 'televisiography' is linked to the idea that '[...] each country has its own television, with different analysis variables which are more complex than those for movies, for example. In television, the fields of content, aesthetics and politics are inextricably linked to their specific characteristics, like the programming, the technological possibilities, competition among different
} 
reciting the works of these authors, what we aim to bring here is a critical view of such works. To that end, all discussions engaged in this space are mobilized from the perspective of a Latin American researcher that tries to go beyond the Global North academic view as the only point of departure and arrival. The aforementioned geographic framework does not prevent new readings on these concepts from being reframed in future research that uses this article as a possible parameter. In addition, the central authors' selection criteria indicate a selection proposed to debate what is considered part of the canon of television studies (John Fiske and John Caldwell), allied to authors who still walk on the sidelines of these discussions at a global level. That is the case with authors coming from the Latin American School of Communication (Jesús MartínBarbero) or even perspectives considered to be atypically mobilized in television studies, such as the theories of embodiment (Alexia Smit).

Likewise, the chronological frame of the selected works (starting from the context of the discussion in the late 1980s to the present), seeks to show how excess is examined from different perspectives over approximately three decades. Thus, the highlight of this chronological frame not only denotes the importance of the topic to television studies but also explains the continuity of a debate that insists on revisiting excess as a complex and singular element in media discourse. Finally, the hypothesis of this work is that the views brought by the authors who conceptualize the five types of excess emphasize that media discourse of the TV is based on excess as an ontologically qualitative discursive production. Under those circumstances, even with different realities in terms of time, space, and televisiographic contexts, excess is part of television language as a medium of social and cultural communication.

\section{Hyperbolic excess and semiotic excess}

In the television context, Fiske (1987) explains that media discourse is pervaded by excess on two levels: excess as hyperbole and semiotic excess. While the first one is centralized in a specific textual device (programs where excess is a display of exaggeration), the second one has a generic feature that permeates all TV broadcasts and not just one program in particular. Despite the different loci of action, both excesses are extremely polysemic, as Fiske (1987) states.

channels and their characteristics, the visibility of public or private channels, whether broadcast or narrowcast, the political conditions for granting and regulation of television, which also involve the social issue, the regionalization or not of production and programming, among others' (Muanis, 2015: 91-92). 
More precisely, we see the hyperbolic excess in the characterization of melodramatic characters and, especially, in the style of acting. We are referring to the histrionic configurations of the characters, as well as the scene composition accompanied by an excess of close-ups, camera movements, and, of course, a sound environment that guides the emotion. In this way, it is clear that there is a dialogue between Fiske's vision and what Baltar (2013) says about excess appearing as an insert - in other words, a reiterative and saturated element that produces symbolizations. This is seen, for example, when melodramatic image and sound are used as aesthetic strategies to create meaning in audiovisual productions (Baltar, 2013).

On this matter, it is important to see how the soap opera acting style (and by extension, some Latin American telenovelas as well) operates as a component of television language that, using the hyperbolic excess, manages to intensify the emotional conflicts of the narrative (Feuer, 1984; Fiske, 1987). It is worth mentioning, however, that even though it is inherent in melodrama, hyperbolic excess is not exclusive to it: sports programs (such as wrestling) and variety programs (such as quiz games) are also permeated by this aesthetic portion of excess in its spectacular configuration (Fiske, 1987).

Besides this, hyperbolic excess acts as a double articulation in the creation of meaning in TV transmission (i.e., in the message) and its reception conditions. As Fiske (1987) asserts, this sort of excess reaches the dominant ideology and, at the same time, adopts a critical position in relation to it. Furthermore, hyperbolic excess also opens a double reception equivalence when the audience can read TV contents positively or negatively in the matter of the original interpretation intended by a specific textual device.

Such double articulations reaffirm the ambiguous feature of a potential political transgression on the hyperbolic excess: depending on the organization of forces that shape television discourse, there may be negotiations between the main text and the subtext (potentially subversive in issues of gender, class, race, etc.) represented in a work, as explained by Fiske (1987). In addition to this ambiguity, Fiske puts the visions of Laura Mulvey and Jane Feuer in opposition on this matter: for the first author, excess is a safety valve that produces hegemonic effects, whereas, for the second one, excess is seen as a potentially radical response to the cultural contradictions in the social world (Fiske, 1987).

In a different approach, semiotic excess acts in a more expanded way on TV, that is, it is not limited to a specific program or genre. Its performance occurs in television emission as it produces such a complex range of meanings that it 
is impossible to police or control them. In other words, the semiotic excess is molded within television language and that makes it impossible for the dominant ideology to control the audience's interpretative capabilities with only the bias of interest or a unique key to reading. 'There are always traces of competing or resisting discourses available for alternative readings' (Fiske, 1987).

The plurality of meanings on semiotic excess (following the dominant ideology or not) dialogues, again, with the ambiguous feature of hyperbolic excess since the fruition of media discourses it is not restricted only to the visible or superficial level of a television's text. Instead, semiotic excess is equally open to other meanings built-in its subtext. That is why it is relevant to highlight that semiotic excess, although being endogenously shaped into the constitution of TV emission, has its own non-anarchic polysemy:

'[...] the meanings within the text are structured by the differential distribution of textual power in the same way that social groups are related according to the differential distribution of social power. All meanings are not equal, nor equally easily activated, but all exist in relations of subordination or opposition to the dominant meanings proposed by the text'. (Fiske, 1987).

Equally important, the modes of representation put in the scene by television's semiotic excess are endowed with an 'excess of meaningfulness' that is formed by two correlated parts: 1) Internally, through the juxtaposition of images, sounds, light, movement, color, time, narrative, genre, word, and compositions; and 2) Externally, through speeches and off-screen social relations (Hartley, 1983; Fiske, 1987). In other words, the spectator (situated in the tradition of reception studies [cultural studies]) also gains an important role in the unveiling of the meanings co-produced by television's semiotic excess and the audience's reading processes. Thus, by not controlling its semiotic potential, television's processes of signification are always and necessarily contradictory because they open spaces for consensus or dissent in what Fiske (1987) claims to be the text of television: '[...] the site of a struggle for meaning'.

\section{Stylistic excess}

The tradition of Anglo-Saxon research on television has Caldwell (1995) as one of its greatest representatives. One of the reasons for this is the redirection of the investigative gaze towards television materiality in a very sui generis field - style. What the author proposes in his work is to envision a language and a discursiveness that not only tries to understand the texts and cultural effects of the television apparatus but also seeks to unveil the stylization process of television image and sound. 
Caldwell (1995) views the American context in the 1980s as a perfect locus for the development of a phenomenon that he claims to be the advance of style as a denotative mark. In other words, style begins to be seen by the cable TV market and audience as a trait of quality and difference among TV broadcasting services. Consequently, stylistic excess turns out to be a translation for a type of television that tries to establish itself as an authentic and autonomous media. Realizing the timely division of a 'before' and 'after', the author states that there would be two broad ways of classifying the aesthetic regimes of TV: zero-degree television and style-television.

By zero-degree television, Caldwell (1995) recognizes the period in which visual homogenization became almost the only way of doing TV, that is, a lack of care or attention in the construction of an image that could be sophisticated or with its own poetics (as opposed to, for example, the cinematographic image). In the case of TV series and other products from broadcast programming, zerodegree television does not see the relevance or even the necessity of having a great production process. Accuracy with elements such as camera angles, depth, texture, point of view, and scenes shot from external locations was not a concern in the daily work routines in this kind of TV. 'Working on the image style was secondary in these productions, which would prioritize the text and not the form, defined by Caldwell as zero-degree television', explains Muanis (2018).

Conversely, in complete opposition to the aforementioned moment, is style-television (also called by Muanis (2018) as a 'television-excess'). It is precisely in this aesthetic regime on TV that Caldwell (1995) establishes the concept of televisuality. According to him, televisuality allows us to perceive how aesthetics and style gain prominence in this new period, to the point of stabilizing themselves as reiterated and institutionalized practices on American TV channels.

As a result, in search of its own poetics, televisuality takes stylistic excess as a crucial element of difference and affirmation. 'Televisuality would represent a change in programs, which would redirect to the spectacularization of the image and, according to the author [Caldwell], to a stylization process', details Muanis (2018). Thus, stylistic excess is discussed as a feature capable of producing an improvement in image quality, that is, greater refinement in the way that sensory and aesthetic appeals are projected on the screen in an attempt to create autonomy and distinction.

Stylistic excess as a form and technological competence permits televisuality to reevaluate style on another level. Since, as Caldwell (1995) says, stylistic excess is not just a byproduct, an overflow effect, or a simple decorative 
distraction for the narrative: 'Rather, excessive visual style is a fundamental way that contemporary television narratives are paraded and performed before viewers' (Caldwell, 1995).

Another subject of special interest to the author concerns the critical and transgressive feature of stylistic excess. Therefore, considering that the interpretation of excess as a subversive potential in relation to the narrative comes from the theories of film analysis, in the specific case of television it is necessary to redouble efforts to avoid problems in this kind of conceptual reallocation and application. Even so, the author reminds us that '[...] stylistic excess can undermine the text's authority, that is, if the viewer chooses to read against the dominant grain [natural tendency] of the text' (Caldwell, 1995).

This appreciation of style in television language is attested by works later than Caldwell's (1995) as is the case of Butler's (2010) studies. In a definition that includes not only the image, but the mise-en-scène, sound, and editing as narrative constructions, Butler (2010) indicates an understanding of style as part of all technical sound-image standards that attest to its function (singular or multiple) in TV media discourse. For the author, 'style is their texture, their surface, the web that holds together their signifiers and through which their signifiers are communicated' (Butler, 2010). According to him, the most apprehensive elements of television language are visible and have the potential to affect us, specifically, through style.

It is also noteworthy that, even so many years after Caldwell's work was published, Butler reaffirms the importance of style for today's TV broadcasters as a tool for brand differentiation and as an appeal for the consumption of their products: 'Distinctive style is a significant weapon used by television practitioners to combat the distraction factor of the modern mediascape' (Butler, 2010). A similar statement is made by Cingolani (2006) when he states that television, in its development in Latin America, was also guided by a peculiar logic of differentiation within its own discourse and style. Rocha (2016), in turn, agrees with Butler's position when she affirms that the analysis of style makes it possible to understand the complexity of TV in terms of production, message, and reception.

Butler also demonstrates how television style is, unfortunately, not taken so seriously in some research that has the TV as its preferred object. Unlike film studies, for example, which has Bordwell (2008) as its main reference (especially from the four broad notions of film style in Bordwell's work: the denotative function, expressive function, symbolizing function, and decorative 
function). However, in the examples found by Butler (2010), it is possible to trace four guiding inclinations in the understanding of style in the television studies field, namely: the descriptive dimension, analytical (interpretive) dimension, evaluative (aesthetic) dimension, and historical dimension.

In addition to Butler (2010), other researchers such as Rocha (2016) and Muanis (2018) also note how, currently, some gaps in television studies persist because of the omission of stylization processes in academic analyses. Rocha (2016) subsequently draws attention to the fact that it is necessary to understand the televisual style in academic studies as an attempt to avoid generalist approaches that ignore the plurality of meanings involved in television's textuality. According to her, it is also important to realize that it is in the structures of stylistic enunciation that the codes and functionalities of the television message materialize. Finally, all of these authors highlight that style in television studies must be seen not as a secondary category, but as a primary guide for research on the relations between excess and discourse on TV.

\section{Bodily excess}

The interest of Alexia Smit (2010) in bringing to the debate the centrality of the body in television discourse necessarily relates to the author's view of the relationship between excess, emotion, and affect in the constitution of communicative performance on TV. Interested in understanding how the intimacy among the multiple bodies involved in television broadcasting is intensified by affect, Smit (2010) turns her gaze to what she calls bodily excess in television discourse. Therefore, debating diverse television genres such as scientific-educational programs and reality shows until arriving at the field of TV series, the researcher seeks to understand:

'[...] not only with the body as it appears onscreen as a representation but with the potential responses of the bodies of viewers at home in their sensate and emotional interactions with television, and, most importantly, with the relationship television fosters between bodies on either side of the screen'. (Smit, 2010)

The author, in this way, sees bodily excess as a mobilizing element of affects, and, for that, she defines her view of affect as '[...] the capacity of a text both to "move" viewers in a physical sense and also to stir their feelings. Affect, in this simple definition, is a stirring of one's bodily responses or of one's feelings', (Smit, 2010). 
In the opposite way, Carina Maguaregui (2004) discusses how the contemporary audiovisual (on television and cinema) has denoted a 'death of affect' in its narrative representations. For her, it is necessary to have a kind of awakening of the moral conscience as a form of counterattacking against what she calls a reification process in a postmodern era. In this 'death of affect' moment, ethics is extremely relativized. For this reason, only after this awakening could the possibility of a 'resurrection of affect' be initially considered (Maguaregui, 2004).

However, even without any direct mention of dialogue between these two authors, it would be erroneous and superficial to say that Smit positions herself as an optimist in relation to a pessimistic thought presented by Maguaregui. What is actually in dispute are two distinct understandings about the status of what the role of affect is in the media discourse. In this way:

1) Maguaregui's (2004) view is symptomatic of the absence of a supposed humanizing affect (in a moralizing sense) in how film and television productions engender cruelty: for example, when condemnable life trajectories of certain characters are presented to the public as typical or normal behaviors to be imitated.

2) Smit's (2010) view, on the contrary, is a structural understanding of affect in television discourse that requires a necessary and profound pragmatic concern with empirical objects that are intensified by what she calls bodily excess. For her, it is only from this point that it could be possible to perceive how affect (as an aesthetic and not just a moral marker) gets involved in relevant discursive strategies. In other words, when affect is understood as a complex phenomenon on TV, it is plausible to recognize how closeness or distance, desire or abjection, stimulus or anesthetization occur in bodies that are in a coresponsive relationship between representation and fruition.

Another posture adopted by Smit (2010) is in relation to the field of emotions. In this way, even while listing authors who maintain conflicting definitions about it, Smit prefers to use both terms (affect and emotion) interchangeably. 'Rather than positing a rigid line of separation between pre-reflective affect and culturally circumscribed emotion I prefer to think of affect and emotion as operating on a fluid line of continuity [...]', states Smit (2010). The researcher's attitude seeks to reestablish the importance of emotion in television studies from a view in which this subject is not perceived as a mere game of exaggerated sentimentality and, therefore, unworthy of reflection.

This division between a place of prominence to 'higher' capacities of reason, as opposed to the 'lowering' of human emotion, is brought up by Didi-Huberman 
(2016) as a way of understanding emotional gestures' status in society. His vision shows how the affect is beyond a superficial perception of emotion as something passive, inept, or irrelevant. Using Hege's philosophy, Didi-Huberman (2016) asserts that it is necessary to rescue and restore pathos to its dignity in relation to logos - something that Smit (2010) engages in by presenting the relevance of the emotional gesture as an important element connected to affect. This relationship, according to the author, is a configuration of symbolic exchanges and processes of meaning in television text. In this sense:

'[...] Sometimes it is necessary for me to make a distinction between these types of feeling, not so much to suggest that they are separate but to emphasise that the emotional is always related to a physical, embodied affective response. The power of affect lies in the way in which emotions and physiology overlap and resonate with each other'. (Smit, 2010).

In the continuity of this argument about the role of emotions and affects, Smit (2010: 29) postulates the concept of tele-afetivity. Based on the discussions brought by Caldwell (1995), especially about stylistic excess and televisuality, the author understands the phenomenon of tele-afetivity in terms of '[...] how excesses of the body on television function as branding strategies to mark programming out as distinct from other television' (Smit, 2010).

Hence, bodily excess is understood as the experiences (fictional or nonfictional, recorded or live) that put in front of us the centrality of the body as a generator of knowledge: a body that is also the originator of practices located in the carnality, in the incorporation, in the embodiment, and in the intensification of intimacy on television. That is, an excess of the body that does not follow the prescription of an 'elevation' of the senses as the reason for processing the senses arising therefrom and, thus, understanding or justifying them.

Accomplishing this, placing excess, body, and affect in the center of the debate, the author points out tele-afetivity as a term that '[...] allows me to draw together ideas about aesthetics and modes of engagement - in particular, theories about embodiment and affect - with a consideration of the industrial and commercial drives that shape the nature of television programming' (Smit, 2010). All bodies in relation share, from tele-afetivity, an intensified intimacy through the bodily excess denoted in television emission. After all, this approach to bodies (in representation and fruition) requires, above all, to think of excess and affect as mobilizing agents and producers of meaning in TV discourse and language. 


\section{Palimpsestic excess}

To think about television and all its transformations over the years, especially in the Latin American context, is a task that involves understanding how temporality, sociability, and leisure relations are linked to the flows and modes of address of television broadcasting (Gomes, 2011; Morley \& Brunsdon, 1999). In this sense, Martín-Barbero's (2009) studies are concerned with discussing how television needs to be seen more than a mere apparatus of social communication. For him, TV is a medium capable of sharing emotions, worldviews, and social values (in disagreement and consensus) pervaded by massive and popular rhetorics, and, most importantly, of mobilizing sociocultural mediations like no other media discourse. This paradigm of study (Mediation Theory) places reception at the center of the debate and not just mass communication media as the usual and almost perennial object of investigation. For this reason, the author brought innovation to the matrices of the Latin American School of Communication in the late 1980s, precisely because it went against the prevailing thought of the Frankfurt School in regional academic circles at the time (Melo \& Gobbi, 2000; Melo, Gobbi, \& Kunsch, 2002).

In the empirical context of Latin American creative industries, television has always played (and is still playing) a fundamental role. As pointed out by Sinclair and Straubhaar (2013), TV has been, over the decades, a powerful element of mass communication, a political instrument, and, above all, an articulator of specific models of social representation. An interesting aspect addressed by the authors is the idea of the region seen as a very similar linguistic and cultural block, that is, Spanish and Portuguese language productions that have their cultural matrices and characteristic industry formats linked to melodrama, the culture of orality, appreciation of fictional narratives, among other points.

As part of the social fabric, TV in the view of Martín-Barbero has something very peculiar in relation to other communication vehicles. Television's multiple forms of reporting and representation are endowed with a very relevant characteristic: the combination possibilities of mixing several genres, formats, and discursive styles that are 'rewritten'. Besides this, television resignify and reiterate its own media discourse excessively and on a daily basis. As termed by Martín-Barbero (2009), this way of 'rewriting' the flow of its productions and message is a palimpsest ${ }^{4}$. According to the researcher, a palimpsest is:

${ }^{4}$ The term comes from the ancient Greek ' $\pi \alpha \lambda i \mu \psi \eta \sigma \tau o v$ ' and means 'again scraped', 'scraped, cleaned and ready to be used again' or 'what you scratch for new writing'. It is a combination of the adverb 'pálin' (again) and 'pséstos' (scraped), past participle of the verb 'psáo' (Barra, 2015a). 
'[...] the oldest and densest form of writing, perhaps the most elementary human form of writing, one that is not inscribed on a wall or column, but on a small wax board. And it turns out that when writing on these little boards - as in our old blackboards - it was necessary to erase the content to start writing again, and then fragments, pieces of words or phrases from the erased writings would reappear, in a confused way, mixing with the newly written words' (MartínBarbero, 2017).

Observing the potential understanding of this metaphor, the author explains how palimpsest configures television discourse by creating networks of meanings. According to him, these meanings overlap in an organized, well thought-out, strategic way. Consequently, time and consumption rituals have fragmentation and reiteration as its greatest semiotic potential on TV. More specifically, Martín-Barbero (2004) borrows the term palimpsest from Italian academic literature as an essential element in the discussion of the television flow $^{5}$. Combined with reflections linked to Raymond Williams (2016), the author states that the television flow must be seen as the complementary device of fragmentation that produces a spatial discontinuity in the domestic sphere at the same time that it pulverizes the notion of time for contemporary immediacy (Martín-Barbero, 2004; 2009). And when performing such actions, the television flow also affects the forms of recording the representation and the '[...] continuum of the television palimpsest [...]' (Martín-Barbero, 2004).

Martín-Barbero points out in the references of his works that the idea of the 'television palimpsest' is derived from the studies brought up by the researcher Guido Barlozzetti (1986). However, it is possible to see that the question is approached with more depth and specificity by Carlo Freccero (1986), author of the chapter 'Il palinsesto della televisione commerciale' ['The palimpsest of commercial television'] - part of the work Il palinsesto: Testo, apparati and generi della televisione [The palimpsest: Text, apparatus, and genres of television] edited by Barlozzetti (1986). It is relevant to highlight this information since it has become common in Latin American academic circles to improperly credit the term 'television palimpsest' to Martín-Barbero when the author himself explains the conceptual origin is from Italian television studies.

${ }^{5}$ Raymond Williams' concept of flow is linked to the idea that what is being shown on television is not, in the old terms, a schedule of separate units with specific inserts, but a planned flow. In other words, this sequence is transformed by the inclusion of another type of sequence, so that these sequences together make up the real flow, or the real TV 'broadcasting'. Therefore, television flow is '[...] the defining characteristic of broadcasting, simultaneously as a technology and as a cultural form' (Williams, 2004). 
Moreover, in the Italian tradition, the idea of 'television palimpsest' has been extremely widespread for a long time, mainly because it is a subject shared by the interests of academia and the TV market. In Italy, the use of 'television palimpsest' has a lot to do with the work routine in broadcasting programming (daily, weekly, monthly, or quarterly) of radio and TV stations. 'Television palimpsest' carries basic information to the viewer such as the names of the programs, the showtime, the type of each individual program, in addition to any other parallel and auxiliary information. Finally, this kind of conception is only possible because, as Barra (2015b) states, the palimpsest is the '[...] result of tactics and strategies, logic and objectives that operate at the editorial, commercial and professional level' of a TV channel.

Nevertheless, the metaphorical notion of palimpsest (as a rewriting, reframing, excessive reiteration, and incessant transformation) still remains today. As Luca Barra (2015a) highlights, the 'television palimpsest' is a 'multifaceted object'. Another way of thinking about palimpsest is in the sense that MartínBarbero (2017) uses the term when calling it a potential 'way of seeing' - a kind of lens to decipher the processes of meaning involved in the logic of palimpsest. Although the author refers to this meaning in the context of a discussion about the city and youth, it is possible to extend this understanding to the television studies field. An understanding that must always, undoubtedly, be contextualized by the cultural matrices and industrial formats of the 'television palimpsest' in the national and transnational television industries, as highlights MartínBarbero (2009). Consequently, palimpsest can be understood, in addition to the written perspective, as a way of reading television and as a mode to understand the audience: 'If, as written, the palimpsest was that erased text, that past that tenaciously emerges, albeit confused, between the lines with which the present is written, we can now assume palimpsest as a way of seeing' (Martín-Barbero, 2017).

In other words, following this view, palimpsest as a 'way of seeing' offers an interpretation key that is extremely productive: it provides an empirical apprehension of analysis and critical questioning of the layers of meaning overlapping constantly and repeatedly in the TV media discourse. The palimpsestic excess, thus, acts in the broadcasting programming, the commercial strategies of differentiation from the competition, the style and tone in the ways of addressing, the discursive construction of the aesthetic regimes of representation, and in the way of establishing itself as a trademark of a TV channel. 
Finally, the television palimpsest (in its relation to television programming) acts on this perspective of reiteration: the excessive 'rewriting' produced by palimpsest is decisive in thinking of how its own structure is endowed with this naturalization of excess, that is, a palimpsestic excess. For this reason, this type of excess is ontologically endogenous to television broadcasting, which, again, reaffirms Fiske's (1987) statements about the existence of a constant semiotic excess in the television flow and not only in certain content that could be considered excessive.

\section{Discussions}

As confirmation of the hypothesis that guides this work, one can say that, even though they start from different social, cultural, political, and economic realities, the discussions brought by Caldwell, Fiske, Martín-Barbero, and Smit present excess under a perspective that escapes the scope of the normative terrain. In other words, a collective view that deviates from the understanding of excess as a quantitative and unnecessary measure. For the authors, considering excess in American, British, and Latin American televisiography, the empirical materiality of excess permeates the realms of production, message, and reception in television studies.

The intersections promoted in the media discourse through theoretical interrelationships between television and excess can be observed, as revealed, from hyperbolic excess, semiotic excess, stylistic excess, bodily excess, and palimpsestic excess. Consequently, it is possible to establish relationships between the five types of excess through three axes: 1 ) The loci of analysis in which excess produces meaning, 2) The ontological nature in which excess manifests itself, and 3) The resulting theoretical composition, that is, the conceptual definition that characterizes the specific type of excess that is discussed.

The loci of analysis are understood as the spaces in which the television broadcast is produced, distributed, displayed, and consumed. In other words, following the discussions brought by Gray and Lotz (2012), the three realms that best represent television media discourse are the production, the message, and the reception. Through these fields, it becomes possible to observe the programs, audiences, institutions, and contexts of each televisiography (Gray \& Lotz, 2012).

The ontological nature of excess is understood from the junctions of Calabrese's (1992) and Dumoulié's (2014) theoretical views. Calabrese's (1992) discussions come from the context of communication and cultural expressions that pass through the binomial of limit-excess in the neo-baroque era. Dumoulié 
(2014), on the other hand, places his discussion in the artistic-literary field. However, in this article, both authors have their reflections reallocated and reframed under the scope of television media discourse.

Calabrese (1992) says that excess can be inferred from three main forms: excess represented as content, excess as structure of a representation, and excess as fruition of a representation. The main focuses of Calabrese's (1992) argumentation are on the first two forms when the author states that they are 'co-necessary' to each other. In other words, the relationship is symbiotic given that the content represented as excessive, in a neo-baroque era, tends to come from a container that is also structurally excessive in its representational form. Such a relationship becomes even more potent when one realizes, based on the author's statement, that excess is internally present: be it represented content or representation structure, in both cases, its materiality is demarcated by an endogenous characterization in mass media. The third form of excess, in turn, is closely linked to the phenomenon of 'performance of fruition' or 'marathon entertainments' within the cinephile community (Calabrese, 1992) - something that today approaches the 'marathons' of watching series, serials, and films for long hours (binge-watching ${ }^{6}$ ).

Subsequently, Dumoulié (2014) exemplifies that excess can be understood ontologically on three levels: thematic excess, the excess originated from aesthetic production, and formal or poetic excess. Accordingly, thematic excess can be found, mainly, from: a) the constitution of excessive characters (in the most diverse genres such as epic, tragedy, comedy, etc.), b) the production of catharsis (considered 'excess therapy'), c) the function of feelings and states of mind such as fury, anger, obsession, and the violence from the passions that end up theming the narratives. The excess located at the origin of aesthetic productions, in turn, is illustrated as a 'source of inspiration' that constitutes an artistic work. According to the author, the basis of the romantic and the modern conception of the genius finds a place in this type of excess. Finally, poetic or formal excess is more directly established in the cultural and artistic vanguards, as in the example of the baroque precisely because this last level translates into an aesthetic of excess itself (Table 1).

${ }^{6}$ Consumption practice that is related to the act of watching some products in streaming media in a flow that, at the pace of the viewer, can give several episodes or even an entire season in a few hours in a row (Silva, 'in-press'). 
Table 1

\begin{tabular}{|c|c|c|c|}
\hline \multirow{4}{*}{ 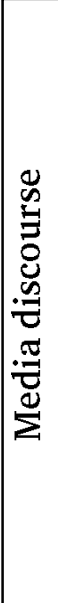 } & $\begin{array}{c}\text { Loci of } \\
\text { analysis [TV] }\end{array}$ & $\begin{array}{c}\text { Ontological } \\
\text { nature }\end{array}$ & $\begin{array}{l}\text { Theoretical } \\
\text { composition }\end{array}$ \\
\hline & Production & $\begin{array}{l}\text { Excess as structure } \\
\text { of a representation } \\
\text { Excess originated from } \\
\text { aesthetic productions }\end{array}$ & $\begin{array}{ll}- & \text { Semiotic excess } \\
\text { - } & \text { Stylistic excess } \\
\text { - } & \text { Palimpsestic excess }\end{array}$ \\
\hline & Message & $\begin{array}{l}\text { Excess as structure } \\
\text { of a representation } \\
\text { Excess represented as content } \\
\text { Thematic excess } \\
\text { Formal or poetic excess }\end{array}$ & $\begin{array}{ll}\text { - } & \text { Hyperbolic excess } \\
\text { - } & \text { Stylistic excess } \\
\text { - } & \text { Bodily excess }\end{array}$ \\
\hline & Reception & $\begin{array}{l}\text { Excess as fruition } \\
\text { of a representation }\end{array}$ & $\begin{array}{ll}- & \text { Hyperbolic excess } \\
\text { - } & \text { Bodily excess } \\
\text { - } & \text { Palimpsestic excess }\end{array}$ \\
\hline
\end{tabular}

Thus, in the context of television production, it is possible to see that semiotic excess, stylistic excess, and palimpsestic excess are interconnected precisely because they are part of the media discourse that is seen in the TV production routine. In other words, these three composite visions of excess are concerned with the way the television broadcast is managed, produced, and built according to the institutionality and the codes of productive contexts of each regional, national and transnational television. These three types of excess in TV production are distributed between two ontologically categorized views of excess, that is, excess as a representation structure and the excess originating from aesthetic production.

Studies that investigate how semiotic excess, stylistic excess, and palimpsestic excess use the structures of representation to produce meaning in television production (e.g., stylistic differentiation of one channel in relation to another, reasons that make a program enter or leave a certain broadcasting programming, etc.) could be situated in this locus of analysis. The creative processes located in the TV production routines also could be established in this perspective as long as it is understood how these three types of excess shape the inspirations behind the constitution of a television program. That is, how the excess located at the origin of aesthetic production becomes revealed by the multiplicity of the content offered in the television broadcast.

Within the locus of enunciation of the television message, it can be seen that hyperbolic excess, stylistic excess, and bodily excess are theoretical compositions that are interrelated in the textuality of television programs. In this perspective, 
investigations that seek to understand the double configuration of excess as a structure of representation and represented content gain prominence. This happens due to the co-dependence of these two ontological forms of symbiotic excess: one cannot analyze the excess present in the message of sensationalist news, for example, without realizing how the show was built, who is part of the editorial decisions, and where the program is located in the grid. Consequently, it is necessary to understand how the content and the container are structurally excessive in their own modes of representation.

Furthermore, research that seeks to understand the hyperbolic excess, stylistic excess, and bodily excess of the television message tends to think of excess through the thematic inclination. This kind of research studies the way the characters express themselves in TV shows and in the way the actions of these characters produce sensory responses in the bodies under discussion (that is, the body of the audiovisual images, the body on stage, and the body that watches such a message). Hence, to study the TV message as a textual form and a place of cultural representation (Mittell, 2010) it is necessary to understand that these three types of excess permeate the media discourse of TV through pervasiveness. Therefore, it is in this instance that the ontological nature of excess is most clearly fluid: it is here that hyperbolic excess, stylistic excess, and bodily excess increase strength to move through different genres, formats, and other productions in TV transmission.

Finally, in the context of television reception, hyperbolic excess, bodily excess, and palimpsestic excess are the three types of excess that place the television audience in the spotlight. Such an analytical framework does not necessarily mean that TV as a medium is subjugated to the empire of the subjectivism of the receiver; on the contrary, it establishes that the poles of emission and reception are co-creators of the processes of producing meaning. Here, of all three loci of analysis, is the space in which the studies on television and streaming are closest.

There is an opening in this locus of analysis (reception) for research that tries to understand how the contemporary practices of binge-watching, bingesearching ${ }^{7}$, and speed-watching ${ }^{8}$ can be understood as technicities that are

${ }^{7}$ Repetitive practice of searching for certain content on streaming platforms at an almost 'marathon' pace. This practice resembles television zapping when the viewer spends long minutes looking for something to watch in the midst of the wide range of productions available on the platform (Silva, 'in-press').

${ }^{8}$ The practice of consuming certain videos on streaming platforms (especially YouTube and Netflix) at a different pace and speed than originally proposed by the broadcaster who uploaded the material. Thus, the viewer intentionally accelerates the video to the playback speed of $0.25 \mathrm{x}, 0.5 \mathrm{x}, 0.75 \mathrm{x}, 1 \mathrm{x}$ (normal pace), $1.25 \mathrm{x}, 1.5 \mathrm{x}, 1.75 \mathrm{x}$ and $2 \mathrm{x}$ (Silva, 'in-press'). 
structured by 'excessive temporalities'. That is, temporalities that are now beginning to be seen as 'ordinary' in the digital consumption of streaming media and TV (Silva, 'in-press'). Then, the aforementioned rituals and sociability of the bodies under discussion turn complementarily towards the understanding of television media discourse and contemporary technological innovations.

\section{Conclusion}

More than just bringing together these views theoretically, the purpose of this work was to assemble views that delimit the discursive complexity of television broadcasting through the ontological path of excess. With an argumentative perspective that concedes how excess is deeply intrinsic to television and its constitution, this article proposed a reading of television discourse and language from five conceptual combinatorial possibilities: hyperbolic excess, semiotic excess, stylistic excess, bodily excess, and palimpsestic excess.

The theoretical and compositional reading of the relationship between television and excess shows the great complexity of television in contemporary times. Hence, the reflection was historically linked to transformations, emergencies, and relationships of mutual coexistence between 'old' and 'new' communication media devices over the decades. It becomes especially clear that those who announce the technological boom of streaming, virtual reality, and immersive network experiences, etc., as potential executioners responsible for the demise of television are, in fact, blinded by an eagerness for innovation.

To produce superficial reflections on the relationship between excess and television only in a pejorative way in which 'excess' is synonymous with lack of sobriety or good taste is to ignore the role of television and sociocultural mediations in television studies. Perhaps, to carry out this type of pejorative reflection is to ignore that the TV media discourse is still one of the biggest motivators of the consumption of information on a large scale and that television represents an important way of experiencing entertainment. To ignore excess on TV is to look away from how television still continually mobilizes rich and complex processes for the construction of national identities, in addition, of course, to the daily conversation of a significant audience around what is presented in television programming. Therefore, to think about television in its complexity is to carefully observe how a) consumer experiences can be mediated or not by other technological devices, b) how society organizes itself and experiences specific rituals through television programming, and c) how people experience sociability that results from television broadcasting. 
In this way, it can be understood that the bond that links hyperbolic excess, semiotic excess, stylistic excess, bodily excess, and palimpsestic excess is based on the ontological qualitative and multifaceted nature of excess. In other words, it is clear that the possibilities of applying these concepts in empirical studies can be stressed in readings that proceed through analyses of production, message, and reception. And, at the same time, the common denominator of all these combinations is located in the compound perspective that excess needs and must be framed as an endogenous characteristic of television. Consequently, excess is something that is part of TV as a complex element present in the constitutions of products and communication processes - an element valuable enough to no longer be understood merely (and even naively) as an unnecessary surplus.

Overall, it is attested that the malleability of the interconnections between the five types of excess demonstrates how excess, in addition to being a pervasive and ontologically qualitative aesthetic-stylistic element, manages to make unlimited combinations across the realms of television broadcasting (production, message, and reception). The presence of the same type of excess in more than one of these loci of analysis mentioned proves the existence of composite configurations in the theoretical formulations of these concepts (e.g., bodily excess in the loci of the message and the reception simultaneously). These configurations demarcate how the five types of excess studied here are multifaceted in terms that vary from content, representation, and fruition, to form, aesthetics, and style.

Excess on television, to emphasize one last time, does not appear on the screen as an indication of a supposed lack of care in the television language in comparison to other expressions and media discourses. The excess that pulsates through modalities such as hyperbolic excess, semiotic excess, stylistic excess, bodily excess, and palimpsestic excess on TV occurs precisely because its enunciation complexity is too vast to be reduced to a mere judgment of taste or value.

\section{References}

BALTAR, M. (2013). Entre afetos e excessos - respostas de engajamento sensório-sentimental no documentário brasileiro contemporâneo [Between affects and excesses - responses of sensorial-sentimental engagement in contemporâry Brazilian documentáry]. Rebeca, 2(4), pp. 60-85.

BARLOZZETTI, G. (1986). II Palinsesto: Testo, apparati e géneri della televisione [The Palimpsest: Text, apparatus, and genres of television]. Milano, Franco Angeli. 
BARRA, L. (2015a). Palinsesto: Storia e tecnica della programmazione televisiva [Palimpsest: History and technique of television programming]. Roma, Editori Laterza.

BARRA, L. (2015b). Sequenze, palinsesti e altri equilibri. Per una storia distributiva della televisione italiana [Sequences, palimpsest, and other balances. For a distributive history of Italian television]. In: D. Garofalo \& V. Roghi, Televisione: Storia, immaginario, memoria [Television: History, imagery, memory]. Soveria Mannelli, Rubbettino Editori, pp. 79-94.

BORDWELL, D. (2008). Figuras traçadas na luz [Figures traced in light: On cinematic staging]. Campinas, Papirus.

BUONANNO, M. (2015). A (premature) eulogy of broadcasting: The sense of the ending of television. MATRIZes, 9(1), pp. 67-85.

BUTLER, J. (2010). Television style. New York \& London, Routledge.

CALABRESE, O. (1992). Neo-baroque: A sign of the times. Princeton, Princeton University Press.

CALDWELL, J. T. (1995). Televisuality: Style, crisis, and authority in American television. New Jersey, Rutgers University Press.

CARLÓN, M. \& SCOLARI, C. A. (2009). El fin de los medios masivos: El comienzo del debate [The end of mass media: The beginning of a debate]. Buenos Aires, La Crujía.

CARLÓN, M. \& FECHINE, Y. (2014). O fim da televisão [The end of television]. Rio de Janeiro, Confraria do Vento.

CINGOLANI, G. (2006). Discursividad televisiva [Television discursiveness]. La Plata, Universidad Nacional de la Plata.

DIDI-HUBERMAN, G. (2016). Que emoção! Que emoção? [What an emotion! Which emotion?]. São Paulo, Editora 34.

DUMOULIÉ, C. (2014) Estética do excesso e excesso da estética [Aesthetics of excess and excess of aesthetics]. A Palo Seco, 6(6), 2014, pp. 46-55.

FAHLE, O. (2006). Estética da televisão: Passo rumo a uma teoria da imagem da televisão [Aesthetics of television: A path towards a theory of television image]. In: C. Guimarães, B. S. Leal, \& C. C. Mendonça, Comunicação e experiência estética [Communication and aesthetic experience]. Belo Horizonte, Editora UFMG, pp. 190-208.

FAHLE, O. (2018). Apresentação [Presentation]. In: F. Muanis, A imagem televisiva: Autorreferência, temporalidade, imersão [The television image: Selfreference, temporality, immersion]. Curitiba, Appris.

FISKE, J. (1987). Television Culture: Popular pleasures and politics. Routledge, New York.

FRECCERO, C. (1986). Il palinsesto della televisione commerciale [The palimpsest of commercial television]. In: G. Barlozzetti, II palinsesto: Testo, apparatie 
géneri della televisione [The palimpsest: Text, apparatus, and genres of television]. Milano, Franco Angeli.

GOMES, I. M. M. (2011). Gênero televisivo e modo de endereçamento no telejornalismo [Television genres and mode of addressing on TV news]. Salvador, EDUFBA.

GRAY, J. \& LOTZ, A. (2012). Television studies. Cambridge/Malden, Polity Press.

INNOCENTI, V. \& PESCATORE, G. (2015). Changing series: Narrativa models and the role of the viewer in contemporary television seriality. Between, 4(8), pp. 1-15.

KATZ, E. (2009). The end of television? The ANNALS of the American Academy of Political and Social Science, 625(1), pp. 6-18.

LADEIRA, J. M. (2016). Imitação do excesso: Televisão, streaming e o Brasil [Imitation of excess: Television, streaming, and Brazil]. Rio de Janeiro, Folio Digital.

MAGUAREGUI, C. (2004). Muerte y resurrección del afecto: Discurso televisivo, conciencia y texto filmico [Death and resurrection of affect: Television discourse, consciousness, and film text]. Buenos Aires, Ediciones de la Flor.

MARTÍN-BARBERO, J. (2004). Ofício de cartógrafo: Travessias latino-americanas da comunicação na cultura [The cartographer's work: Latin American crossings of communication in culture]. São Paulo, Edições Loyola.

MARTÍN-BARBERO, J. (2009). Dos meios às mediações: Comunicação, cultura e hegemonia. [Communication, culture and hegemony: From the media to mediations]. Rio de Janeiro, Editora UFRJ.

MARTÍN-BARBERO, J. (2017). A comunicação na educação [Communication in education]. São Paulo, Contexto.

MELO, J. M \& GOBBI, M. C. (2000). Gênese do pensamento comunicacional latinoamericano [Genesis of Latin American communicational thinking]. São Bernardo do Campo, Unesco/Universidade Metodista de São Paulo.

MELO, J. M, GOBBI, M. C., \& KUNSCH, W. L. (2002). Matrizes comunicacionais latino-americanas: Marxismo e cristianismo [Latin American communicational matrices: Marxism and christianity]. São Bernardo do Campo, Unesco/Universidade Metodista de São Paulo.

MISSIKA, J.L. (2006). La fin de la télévision [The end of television]. Paris, Seuil.

MITTELL, J. (2010). Television and American culture. New York, Oxford University Press.

MITTELL, J. (2011). Notes on rewatching. JustTV. Available from: https://justtv. wordpress.com/2011/01/27/notes-on-rewatching/

MORLEY, D. \& BRUNSDON, C. (1999). The nationwide television studies. London, Routledge. 
MUANIS, F. (2015). The worst television is better than no television. MATRIZes, 9(1), pp. 87-100.

MUANIS, F. (2018). A imagem televisiva: Autorreferência, temporalidade, imersão [The television image: Self-reference, temporality, immersion]. Curitiba, Appris.

ROCHA, S. M. (2016). Estilo televisivo e sua pertinência para a TV como prática cultural [Television style and its relevance to TV as a cultural practice]. Florianópolis, Insular.

SILVA, A. L. ('in-press'). Temporalidades excessivas: as práticas de bingewatching, binge-searching e speed-watching no consumo de streaming [Excessive temporalities: binge-watching, binge-searching, and speed-watching on streaming consumption practices]. Temática, in-press.

SINCLAIR, J. \& STRAUBHAAR, J. D. (2013). Latin American television industries. London, British Film Institute/Palgrave Macmillan.

SMIT, A. J. (2010). Broadcasting the body: Affect, embodiment and bodily excess on contemporary television. Ph.D. Dissertation (Film and Television Studies), University of Glasgow, Glasgow, UK.

SMITH, M. D. \& TELANG, R. (2017). Streaming, sharing, stealing: Big data and the future of entertainment. Cambridge, MIT Press.

THORBURN, D. (1976). Television melodrama. In: H. Newcomb, Television: The critical view. New York, Oxford University Press, pp. 595-608.

WILLIAMS, R. (2004). Television: Technology and cultural form. London, Routledge. 